\title{
FORMA, DISCURSO E IDEOLOGÍA EN EL MENSAJE PUBLICITARIO
}

\author{
Juan Rey \\ (Universidad de Sevilla) \\ juanrey@us.es
}

\section{Resumen:}

Se trata de delimitar los conceptos 'forma', 'discurso' e 'ideología', en el ámbito publicitario. La forma y el discurso son la unidad y la totalidad de la comunicación publicitaria. $Y$ ambas se cobijan bajo la ideología (consumista). Sus relaciones son complejas y heterogéneas. La forma remite al discurso y éste, a su vez, remite a la ideología. Inversamente, la ideología se manifiesta a través de los discursos (uno de ellos es el publicitario), de la misma manera que estos se encarnan en las formas.

Palabras clave: Publicidad, forma, discurso, ideología.

\section{Abstract:}

This paper tries to define the concepts format, discourse and ideology in advertising. Format and discourse are the unity and the entire of communication advertising. And both are sheltered under the (capitalist) ideology. Their connections are complex and heterogeneous. The format refers to the discourse, and this, as well, refers to the ideology. On the other hand, the ideology is manifested through discourses (one of them is the advertising one), in the same way that these are embodied in the formats.

Key words: Advertising, format, discourse, ideology.

\section{INTRODUCCIÓN}

omo punto de partida puede afirmarse que toda forma publicitaria es una manifestación del discurso publicitario y que éste, a su vez, es el soporte conceptual que la sustenta. Forma y discurso son, pues, respectivamente la unidad y la totalidad de la comunicación publicitaria. Una no se entiende sin la otra, una remite a otra, una explica la otra. Por su parte, la ideología es el paraguas que cobija y da sentido al discurso y a la forma. A continuación se procederá al análisis de los conceptos de forma y discurso a fin de establecer sus relaciones con el fin de ubicarlos en el contexto de la ideología, la consumista en este caso.

\section{LA FORMA PUBLICITARIA}

Para dar una acertada definición de forma publicitaria es necesario proceder mediante aproximación. La ecuación establecida entre forma y discurso publicitarios es 
Forma, discurso e ideología en el mensaje publicitario

similar a la existente en el ámbito académico entre texto y discurso. Dado este paralelismo, es conveniente proceder al análisis de estos dos últimos conceptos para llegar a una definición de forma. ¿Qué se entiende por texto? Un primer acercamiento lo proporciona la Real Academia Española en su Diccionario de la lengua española al afirmar que es un "Conjunto de palabras que componen un documento escrito" o bien un "enunciado o conjunto de enunciados orales o escritos, que el lingüista somete a estudio". María Moliner, en su Diccionario de uso del español, establece que un texto es "Escrito cualquiera con cierto contenido; contenido de un escrito".

Ambas definiciones insisten en la relación entre texto y lengua, ya sea oral o escrita. En principio, texto es sólo aquello que se dice o escribe. Esta concepción dificulta la aproximación a la definición de forma publicitaria, ya que ésta, además del componente escrito o hablado, presenta otros formantes (música, dibujo, ruidos, pintura, luz...). Felizmente para la publicidad, la concepción tradicional de texto ha sido superada y esta superación se ha desarrollado en una doble dirección. Primera, gracias a los estudios de semiótica, el concepto de texto se ha ampliado. Y segunda, en el seno de los recientes estudios textuales, el texto, aun sin perder el carácter de escrito/hablado, es analizado desde otras perspectivas. Los primeros ofrecen una nueva definición de texto gracias a la cual pueden también estudiarse, desde una óptica mucho más rigurosa que la meramente interpretativa y subjetiva, realidades tales como una pieza musical, una obra de arte o un mensaje publicitario. Los segundos, aun permaneciendo fieles al postulado de que un texto es algo escrito/hablado, proporcionan toda una batería de conceptos, máximas y principios que son de gran utilidad para abordar el estudio de las formas publicitarias.

\subsection{La irrupción de la semiótica}

La concepción tradicionalista del texto perduró incluso durante el imperio estructuralista y generativista, y estuvo vigente hasta que, en 1968, Umberto Eco afirmó taxativamente que "no todos los fenómenos comunicativos pueden ser explicados por medio de categorías lingüísticas" (1989: 187). Terminaba así el absolutismo lingüístico que impedía cualquier análisis riguroso de los mensajes no verbales. La aplicación sistemática de los postulados lingüísticos -en especial la segunda articulacióna cualquier otro tipo de comunicación imposibilitaba todo avance en el análisis de las nuevas formas de comunicación, ya que, al carecer de ese doble mecanismo, enseguida eran descalificadas como sistema de comunicación y, por tanto, incluidas en una categoría inferior a la que ocupaba la lengua, modelo de comunicación único, indiscutible e incuestionable hasta el momento.

Sin embargo, el desarrollo tecnológico ha posibilitado que en la actualidad el hombre genere cientos de mensajes cuya forma y organización distan mucho de parecerse a los verbales. Piénsese en una comedia de situación, una valla, un spot, un videoclip o un banner. Por todo ello puede decirse que el planteamiento de Eco fue beneficioso para la publicidad, porque su postura abrió nuevas perspectivas para analizar todos aquellos elementos que conforman el mensaje publicitario. Un anuncio en prensa se basa en la imagen y ésta, desde la perspectiva tradicional, era difícilmente analizable (o se analizaba de manera impresionista, subjetiva). Lo mismo sucedía con la música o la imagen dinámica de los filmlets o los spots. Es cierto que 
Juan Rey

los estudios de semiótica han proporcionado una dosis de rigor al análisis de los mensajes publicitarios, pero también es cierto que lo han hecho acompañado de un oscurantismo terminológico que la mayoría de las veces ha ensombrecido sus propias aportaciones, una de las cuales, y quizás la más importante, es la redefinición del concepto de texto: "Texto es cualquier conjunto coherente de signos" (Lozano et ali, 1993: 16-19). Como puede observarse, a pesar de ser una definición bastante amplia, se apoya en dos nociones básicas: a) la de signo, y b) la de conjunto o sistema. La explicación de cada una de ellas servirá de gran ayuda para entender la concepción moderna de texto, y por tanto de forma.

En cuanto al signo, éste ya no es definido en términos lingüísticos. Ya no se trata de un fenómeno verbal o escrito, sino que cualquier objeto, sonido, gesto, color, música, imagen o instrumento que comporte un significado, es considerado signo. La superación de la concepción lingüística del signo supuso, simultáneamente, la negación del imperativo de que el texto estuviese compuesto sólo por signos simbólicos. Los signos icónicos y también los indicios pueden constituir un texto. De esta manera, un texto puede estar compuesto por símbolos (palabras orales o escritas, ciertos elementos de la señalética, gestos, movimientos), por iconos (imágenes estáticas o dinámicas, ciertos elementos de la señalética, croquis, planos) o por indicios (sintomatología médica). Es decir, hoy se entiende por signo la conjunción de un elemento formal (significante) y otro conceptual (significado), al margen de su naturaleza y de su manera de relacionarse.

En cuanto a la noción de sistema, cada uno de los integrantes anteriormente mencionados forma parte de un conjunto diferente. Los hay sonoros (palabras, ruidos, música) y visuales (luces, colores, letras, imágenes). Unos imitan la realidad (imágenes, ruidos) y otros no (palabras, letras, música). Pero, al margen de esta clasificación, puede establecerse otra basada en la forma que cada uno de estos sistemas tiene de organizarse. También en este terreno fueron de gran utilidad los planteamientos de Eco. La noción de sistema, tomada de la lengua, dificultaba el análisis de las modernas formas de expresión. Todo intento de estudio quedaba automáticamente bloqueado porque estas nuevas formas se organizaban de modo distinto a como lo hacía la lengua. En ésta, los elementos pertinentes son muy superiores a las variantes facultativas y se relacionan entre sí mediante una compleja red de reglas y normas. Esta distribución y conexión son las que garantizan una correcta interpretación del mensaje. En las nuevas formas, en cambio, las variantes facultativas son, a veces, muy superiores a los rasgos pertinentes y, además, se relacionan entre sí escasamente, dado que las reglas son pocas y, cuando existen, resultan ambiguas o muy flexibles o excesivamente laxas. Esta inversión es la que dificulta en gran medida la correcta interpretación del mensaje. $Y$ la que ha originado que se les niegue la categoría de sistema. También en este sentido fue tajante la postura de Eco: "La doble articulación no es un dogma" (1989: 220). Y como no es un dogma afirma- no tiene por qué ser respetado a la hora de analizar las nuevas formas de comunicación. Y como solución a este problema propone una nueva clasificación de los códigos visuales: muy potentes, potentes y débiles (1989: 202-207).

Se trata de tres tipos de códigos que se distinguen entre sí, no sólo por la naturaleza de sus unidades o el tipo de relación que mantienen entre ellas, sino que también se diferencian por las repercusiones que tienen en el receptor a la hora de 
Forma, discurso e ideología en el mensaje publicitario

interpretarlo. Los primeros y segundos son sistemas muy cerrados. Esta organización facilita su interpretación, ya que toda la información está contenida en el mensaje y el receptor, si conoce el código, apenas debe esforzarse para comprenderla. Esa facilidad se debe a la escasa existencia de variaciones y la extremada codificación del mensaje. Puede afirmarse, pues, que, cuando se emplean estos códigos, el emisor se lo da casi todo hecho al receptor. En este caso, las posibilidades de error son mínimas. Por el contrario, al emplear códigos débiles, las posibilidades de error son muy superiores, porque se trata de sistemas abiertos en los que la información apenas está contenida en las unidades pertinentes sino que el receptor debe inferirlas a partir de las variaciones facultativas. Puede decirse, pues, que, al hacer uso de este tipo de código, la labor del emisor es menor que en los casos anteriores y que, en cambio, la de receptor es mucho mayor, ya que se ve obligado a completar, suponer o deducir la información que falta para comprender el mensaje, actitud cooperadora (y forzada) que en cierto modo favorece la aparición de errores de interpretación.

Sin embargo, contradiciendo toda lógica de eficacia comunicativa, no sucede así en publicidad, ámbito en el que el uso y abuso de códigos débiles plantea la siguiente cuestión: si lo que se pretende es alcanzar un público objetivo de manera clara y directa para transmitirle, con la mayor rapidez posible, un mensaje cerrado y coherente, un mensaje que, a pesar de las condiciones adversas de recepción, pueda entenderlo unívocamente de modo que lo incite a actuar en una dirección concreta, ¿cómo es que, en vez de utilizar códigos que aseguren una correcta descodificación del mensaje, se emplean aquéllos otros que no la aseguran o la aseguran parcial o defectuosamente? La solución a este dilema se halla en: a) el repertorio a partir del cual el emisor compone el mensaje, y b) la experiencia y la capacidad interpretativas del receptor.

Cuando el emisor elabora su mensaje, acude a un formulario de símbolos, conceptos y estrategias que forman parte del imaginario colectivo. Todo lo que vaya a decir ya ha sido dicho, y codificado, conceptual y visualmente. Ya Aristóteles estableció en sus Tópicos cuáles son los lugares comunes, las ideas básicas, los conceptos fundamentales, los topoi, para decirlo en griego, a partir de los cuales se formula toda argumentación y, por ende, toda persuasión. En este sentido, la publicidad lo que hace es aprovecharse de un caudal preexistente. Sus mensajes son nuevos en la forma, pero en el fondo son tan viejos como la humanidad. La búsqueda de la felicidad, la atracción de la belleza, el afán de originalidad, la seducción de lo prohibido, el triunfo del bien sobre el mal..., no son sino viejos tópicos que, después de sobrevivir miles de años en novelas, esculturas y cuadros, surgen ahora envueltos en los modernos ropajes de la publicidad.

Los mensajes publicitarios no plantean problemas de interpretación porque, según Adam y Bonhomme, se apoyan en esquemas icónicos y topos conceptuales (2000: 246). Los esquemas icónicos son "estructuras visuales", representaciones simplificadas que permiten un rápido reconocimiento y, simultáneamente, corrigen cualquier error de interpretación. Un hombre joven que porta en brazos a un bebé es el esquema icónico del padre cariñoso y protector, el padre moderno; un grupo de jóvenes reunidos en torno a una botella de alcohol o una cajetilla de cigarrillos, el de la convivialidad; un hombre y una mujer jóvenes y bellos, el del amor; o un hombre ma- 
duro, canoso, con entradas, bata blanca y gafas, el del científico o el médico expertos. Esta facilidad de interpretación se debe a que los esquemas icónicos no son sino la traducción visual de los topos conceptuales de larga tradición. Y es justo esta codificación rigurosa lo que le permite al receptor reconocerlos rápidamente e interpretarlos con facilidad.

Pero del mismo modo que el emisor dispone de unos instrumentos para elaborar sus mensajes, el receptor dispone de otros para entenderlos. De esta manera, queda asegurada la correcta interpretación del mensaje. En primer lugar, el destinatario cuenta con su propia experiencia. Es una obviedad, pero es algo que no debe olvidarse ni menospreciarse. Cuando un receptor español actual, por ejemplo, se enfrenta a un mensaje publicitario cuenta con todo un bagaje interpretativo. Sería distinto si ante el mensaje se hallase un individuo venido de una sociedad en la que no existiese la publicidad tal como se entiende en una sociedad de consumo. Esta diferencia se fundamenta en la experiencia particular acumulada por cada uno de ellos. Al receptor español, cuando se encuentra delante de un anuncio, le asiste, aunque no se percate de ello, toda la experiencia almacenada y asimilada durante la observación, análisis e interpretación de miles de mensajes publicitarios anteriores. Reconoce enseguida el anuncio e identifica sus estructuras y colores, de modo que, con una simple ojeada, sabe ante qué tipo de mensaje se halla. Puede decirse que, más que una interpretación, lo que el receptor lleva a cabo es un re-conocimiento, una identificación (Eco, 1989: 294).

El receptor, en segundo lugar, cuenta con su propia capacidad interpretativa, capacidad que guarda una estrecha relación con la experiencia acumulada y con el ámbito cultural en el que se desenvuelve. Son muchos los estudios sobre los itinerarios que el receptor recorre o debe recorrer hasta llegar a la interpretación más o menos correcta del mensaje. Como punto de partida pueden tomarse los postulados de Erwin Panofsky, quien en sus estudios sobre iconología establece tres niveles: perceptivo, identificativo e interpretativo (1994: 13-44). Estos tres niveles son consecutivos y eliminatorios. El primer nivel es puramente biológico, se trata sólo de ver, de tener la capacidad de percibir la realidad a través del sentido de la vista. En el caso de que el receptor estuviese incapacitado visualmente, no podría proseguir el recorrido a través de los dos niveles restantes, que ahora ya son culturales. Una vez visto el mensaje, identifica lo que ve, es decir, reconoce formas, colores, objetos y figuras. Y por último interpreta lo que ha visto e identificado. He aquí un ejemplo. Ante una foto, el receptor ve, primero, e identifica, después, una serie de elementos: el busto de un hombre joven con una barba rala y desigual, el rostro ligeramente dirigido hacia el ángulo superior derecho, la mirada perdida en el horizonte, el cabello - largo y desordenado- asomando por debajo de una boina en cuya parte frontal figura una estrella, y todo ello en blanco y negro. Si el receptor perteneciera a una cultura distinta, pudiera suceder que no reconociera la prenda con la que el hombre joven se toca la cabeza. Por último interpreta lo que ha visto. Gracias a este nivel, va más allá de lo meramente percibido e identificado, pues para él todos estos elementos configuran la imagen del Che Guevara, símbolo de la rebeldía y la revolución. Pero, si desconociese la historia de este guerrillero y su contexto histórico, no superaría el nivel identificativo y, por tanto, no podría interpretar el mensaje. La misma operación puede aplicarse a cualquier mensaje publicitario, ya que la publicidad hace tiempo que superó los planteamientos informativos o denotativos para adentrarse 
Forma, discurso e ideología en el mensaje publicitario

en un terreno simbólico o connotativo, ámbito éste mucho más rico y expresivo que aquél y con mayor capacidad y posibilidad de comunicación, siempre y cuando el receptor conozca los códigos y sepa interpretarlos correctamente. En este sentido, ante la imagen de un hombre joven, elegante, con maletín y corbata, el receptor interpreta que está delante del clásico triunfador del cosmos publicitario: el yupi.

\title{
2.2. La llegada de los estudios textuales
}

Los modernos estudios textuales son fruto de un largo proceso de investigación y análisis sobre el texto que comienza con la retórica clásica y culmina a comienzos del siglo XXI. Para muchos teóricos, los retóricos son los primeros en preocuparse por el texto en su globalidad. En la segunda mitad del siglo XX, el texto ha vuelto a llamar la atención de los investigadores. En los años cincuenta, Chaïm Perelman inicia la recuperación de la antigua retórica con una serie de estudios que han arrojado mucha luz sobre los mecanismos de construcción y organización del texto y, en los setenta, un grupo de estudiosos emprende una serie de análisis que ha culminado en lo que actualmente se denomina lingüística del texto, gramática del texto, teoría del texto o estudios textuales, y cuyo objeto de estudio es tanto el texto, visto ahora en su totalidad, como el contexto en el que se elabora, ejecuta y recibe. Como puede observarse, los modernos estudios textuales le deben más a la cooperación de otras disciplinas (teoría de la comunicación, psicología cognitiva, sociología o antropología) que a la lingüística tradicional. Y ello es así no sólo porque la teoría del texto desborda la frase sino también porque supera la noción misma de texto y se adentra en terrenos (el contexto) para cuyo análisis la lingüística necesita el concurso de esas otras disciplinas.

¿Qué entienden por texto los estudios textuales? En principio, todos los autores están de acuerdo en que el texto es una unidad comunicativa. Es decir, el punto de partida para definirlo desborda el ámbito de la lingüística tradicional para adentrarse en el terreno de la teoría de la comunicación y se le define como una unidad de intercambio entre un emisor y un receptor con una finalidad determinada:

\begin{abstract}
El texto es la unidad mínima de información, de comunicación y de interacción social, y todo ello conjunta y simultáneamente, pues la información se almacena para ser transmitida a un organismo receptor que, necesariamente, debe reaccionar a ella, ya sea incorporándola a su caudal de conocimiento, ya sea transformando su actitud o su carácter [...]. Texto es la unidad mínima de interacción comunicativa [...]. El texto puede ser muy breve y muy simple, estar compuesto por una sola frase [iPeligro!], o ser extenso y complejo, compuesto por cientos de frases [Cien años de soledad] (Núñez y Del Teso, 1996: 175) (el texto entre corchetes es nuestro).
\end{abstract}

Esta definición de texto, dada la cantidad de nociones que incorpora (información, comunicación, almacenamiento, interacción social, transmisión, recepción del destinatario, reacción del receptor, transformación de su carácter, variedad de presentación) podría ser de gran utilidad para definir el concepto de forma publicitaria, sin embargo tiene el inconveniente de estar demasiado apegada al concepto tradicional de texto. Es decir, no supera el verbalismo inherente a toda gramática, sea tradicional o moderna. La única manera de aprovechar esta definición para el propósito inicial es sustituir el concepto tradicional de texto (escrito/hablado) por otro más am- 
plio proporcionado por los semióticos (conjunto coherente de signos). Si se opera esta permuta, puede observarse que la noción de texto varía enormemente y que esta variación permite analizar las diferentes formas bajo las que se presenta la publicidad. En este sentido, una vez llevada a cabo la sustitución, es fácil aplicar estas nociones a una inserción en prensa, una valla, un spot, una cuña o un banner.

Pero además de por el texto, los estudios textuales se preocupan por el contexto, entendido éste en un amplio sentido. Es decir, se preocupan por todos aquellos procesos que rodean tanto la elaboración como la ejecución y recepción del texto. Así, pues, si el texto es "la unidad mínima de interacción comunicativa", nada tiene de extraño que se recurra a la teoría de la comunicación para explicar algunos de tales procesos. Beaugrande y Dressler, partiendo de las ideas de intencionalidad y planificación que subyacen en toda comunicación, establecen que cualquier texto, para ser considerado tal, ha de respetar las siete normas de textualidad: cohesión, coherencia, intencionalidad, aceptación, informatividad, situacionalidad e intertextualidad (1997: 76).

La cohesión hace referencia a las relaciones que deben mantener entre sí todos los componentes del texto. La sintaxis es la encargada de regular y coordinar estas relaciones y dependencias (1997: 89-134). El texto publicitario, tomado ahora en el sentido semiótico del término, también ha de estar cohesionado. Sus integrantes, pertenezcan al código que pertenezcan, deben guardar entre ellos una estrecha relación a fin de que el receptor interprete correctamente el mensaje. Por ello, la imagen debe guardar una estrecha relación con el título y éste con el cuerpo de texto, si se trata de una inserción en prensa; y el sonido (palabras o ruidos) con la imagen, si se trata de un spot, etc.

Sin embargo, en publicidad, al tratarse de un código débil, las relaciones son más laxas y las unidades significativas menos delimitadas, lo que, en cierto modo, obliga al mensaje publicitario a potenciar aún más las relaciones y dependencias entre sus diferentes elementos a fin de dotarse de una cohesión que la naturaleza de su propio código le niega. Muchos de los mecanismos que se dan en la lengua para facilitar la cohesión aparecen también en el mensaje publicitario. La repetición total, la repetición parcial, el paralelismo, la paráfrasis o la elisión, por ejemplo, están presentes no sólo en el título o el cuerpo de texto de los mensajes publicitarios -es indispensable, ya que se trata de un texto escrito o hablado-, sino también en la imagen.

La coherencia hace referencia a las relaciones conceptuales que deben mantener entre sí las diferentes partes del texto para que el receptor interprete el sentido que quiere el emisor. Cualquier texto es portador de diferentes significados, todos ellos virtuales, sin embargo en una realización concreta sólo posee un sentido. Si no sucede así, surgen problemas como la ambigüedad o la polivalencia, que se acentúan cuando el receptor no encuentra conexión entre las diferentes partes del texto que termina pareciéndole un sin-sentido (1997: 135-168). La coherencia es fundamental en el mensaje publicitario, debido a que, al estar compuesto por dos integrantes distintos - uno de los cuales es la imagen, código débil, de escasas unidades y conexión relajada- la pluralidad de significados está asegurada y, en consecuencia, puede llevar al receptor a no comprender el mensaje (sin-sentido), interpretarlo de manera incorrecta (ambigüedad), o elegir un sentido no querido o no previsto por el emisor (polivalencia). Y en este caso habrá fallado la comunicación. 
Forma, discurso e ideología en el mensaje publicitario

Pero la pluralidad de significados que ofrece la imagen es precisamente el factor que hace que el mensaje publicitario no sea cerrado ni denotativo y, por tanto, resulte más atractivo para el receptor que, al no recibir un sentido dado de antemano, se ve en la tesitura de inferir el sentido otorgado por el emisor. Entonces es necesario formularse ahora las siguientes cuestiones: ¿coherencia, hasta dónde? y ¿libertad de interpretación, hasta qué punto? El emisor publicitario debe saber conjugar coherencia y libertad a fin de no ahogar la capacidad interpretativa del receptor, pero al mismo tiempo debe asegurarse de que éste interpreta correctamente el mensaje.

Si las dos normas anteriores son de carácter lingüístico, la intencionalidad y la aceptabilidad son de tipo psicolingüístico y se centran en las actitudes de los usuarios hacia el texto (1997: 169-199). La intencionalidad hace referencia a la finalidad que el emisor le otorga a su texto. La aceptabilidad, a la credibilidad que le concede el receptor. Estas dos normas son fundamentales en el ámbito publicitario, en el que se da una comunicación intencionada, es decir, pagada por un anunciante, con el objetivo de que el receptor la acepte y, en lo posible, termine convirtiéndose en cliente. Si ningún texto es gratuito, mucho menos lo es el mensaje publicitario, que está sometido al imperativo económico y que, si se emite, lo hace debido a una intencionalidad muy concreta: modificar la conducta del destinatario.

Para que el texto cumpla sus fines, el emisor debe colaborar a que la comunicación sea lo más concisa, auténtica, informativa y clara posible, con el objeto de lograr la aceptación del receptor. En este campo ha sido la pragmática la disciplina que ha arrojado luz sobre la indispensable cooperación del emisor en conversación en la que está implicado. El principio de cooperación establece que, en cada momento, el emisor debe contribuir a facilitar el intercambio comunicativo. Este principio general se desglosa en cuatro máximas: cantidad, calidad, relación y manera. La máxima de cantidad aconseja que sólo se le facilite al receptor la información que necesite en ese momento. Nunca más. Tampoco menos. La de calidad, que siempre se le diga la verdad o aquello que pueda probarse. La de relación, que sólo se le facilite información relevante. La de manera, que los textos sean breves, ordenados, claros y unívocos. Ni que decir tiene que el emisor publicitario, si pretende lograr sus objetivos, debe contribuir al intercambio comunicativo y, por tanto, sus mensajes deben estar presididos por estas cuatro máximas.

La informatividad, de carácter computacional, hace referencia al grado de previsibilidad o imprevisibilidad que presenta el texto para el receptor (1997: 201-224). El nivel de informatividad de un texto depende tanto de su contenido como de las expectativas y conocimientos del receptor. En el caso del mensaje publicitario, es necesario distinguir entre la informatividad en el terreno conceptual y en el formal. Relacionando el grado de informatividad/no-informatividad con los aspectos conceptuales y formales, se obtiene la siguiente tipología: a) mensajes que presentan redundancia formal y redundancia conceptual, b) mensajes que presentan información formal y redundancia conceptual, c) mensajes que presentan redundancia formal e información conceptual, y d) mensajes que presentan información formal e información conceptual (Eco, 1989: 260-273). Sin embargo, no todos ellos tienen idéntica presencia en el mundo publicitario. Los más frecuentes son los dos primeros, los que presentan redundancia conceptual. $Y$ de ambos, el más habitual es el segundo: el que presenta informatividad en el terreno de la forma. 
Conceptualmente el mensaje publicitario presenta un grado de novedad cero, pues se limita a cantar las bondades del producto o servicio en cuestión, magnificar el ambiente de consumo o elogiar a los consumidores ideales, acciones todas ellas que el receptor prevé de antemano en cualquier mensaje publicitario. Es decir, las expectativas y conocimientos del receptor coinciden con el contenido del mensaje. Sin embargo, en términos generales, el mensaje publicitario sorprende al destinatario, no por el contenido, que ya lo presupone, sino por la forma. Se trata, pues, de un mensaje que, a pesar de decir siempre lo mismo, lo expresa de forma diferente, ya para destacar de otros mensajes publicitarios, ya para llamar la atención del receptor, ya para sobresalir en la jungla comunicativa en la que a diario se adentran los receptores. Este abuso de la forma ha llevado a algunos autores a tildar la publicidad de nuevo manierismo. Y en cierto modo no les falta razón, ya que la publicidad, dado que sólo puede hablar de lo que se sabe, se ve obligada a manifestarlo de otra maniera. Y ha sido esta incesante búsqueda de manieras distintas lo que la ha conducido a un formalismo exacerbado, formalismo detrás del cual se esconde lo que ya se conoce, lo que ya se sabe, lo que se espera que se diga.

Las dos normas restantes son de carácter sociológico. La situacionalidad hace referencia a los factores que determinan que un mensaje tenga sentido en la situación en la que aparece (Beaugrande y Dressler, 1997: 225-248). Hay que tener en cuenta que, en términos generales, las condiciones de recepción del mensaje publicitario son desfavorables. Nadie compra un periódico para ver las inserciones, ni se sienta delante de un televisor para contemplar los spots, ni conduce por la ciudad para mirar las vallas. En estos tres casos, la publicidad es algo que el receptor no busca pero que se encuentra. Esta especie de asalto repentino hace que las condiciones de recepción no sean las adecuadas. Y el emisor publicitario lo sabe. Y también sabe que el mensaje que debe construir depende del tipo de recepción. Es decir, la situacionalidad afecta a los medios que determinan la cohesión del mensaje.

He aquí un ejemplo. Un conductor o un transeúnte disponen de escasos segundos para ver, leer y comprender una valla. La situacionalidad establece, pues, cómo se ha de organizar este mensaje exterior para que el destinatario lo perciba y asimile en los pocos segundos de que dispone: a) reduciendo el número de sus integrantes, b) aumentando su tamaño, c) potenciando la imagen, y d) reduciendo el texto. Muy distinta organización presentaría el mensaje publicitario si se tratase de una cuña o una carta comercial. En el primer caso, la temporalidad sería el factor determinante para construir el mensaje. En el segundo, la espacialidad. Aquél se desarrolla en el tiempo. Éste, en el espacio. En la publicidad radiofónica, el emisor es quien controla (impone) el ritmo de recepción. En la directa, es el receptor. Y todas estas condiciones, derivadas de la situacionalidad, son las que inciden en la forma de construir y presentar el mensaje. En otros términos, las que determinan que una forma publicitaria sea idónea para una situación y no para otra. Pero así como el emisor conoce y contempla las premisas de situacionalidad a la hora de elaborar sus mensajes, también el receptor las conoce y las aplica adecuadamente, de manera tal que desarrolla el proceso de interpretación a partir de las condiciones espacio-temporales en las que tiene lugar la recepción.

La intertextualidad se refiere a la relación de dependencia que existe entre un texto dado y otros anteriores (1997: 249-281). En el terreno de la publicidad, el concepto de intertextualidad es doble, ya que puede referirse tanto a la relación, que desde un punto de vista estructural, guarda un mensaje con otros similares como a 
Forma, discurso e ideología en el mensaje publicitario

la relación que ciertos textos publicitarios mantienen con otros procedentes de ámbitos distintos. En el primer caso se hablaría de tipología. En el segundo, de intertextualidad propiamente dicha. En cuanto a la tipología, cuando un receptor, hojeando un periódico, se detiene en el anuncio de una inmobiliaria, lo primero que hace es comparar ese anuncio con otros similares: confronta la estructura, coteja los integrantes... Es decir, compulsa ese anuncio con otros archivados en su memoria con el fin de verificar que se halla ante un tipo determinado de mensaje. Tanto la comparación como verificación las realiza a partir de su propia experiencia, pues como receptor de publicidad sabe que los anuncios de inmobiliaria son casi idénticos desde el punto de vista organizativo, y los de alcohol, y los de coche, y los de detergentes... Puede suceder, y a veces sucede, que un anuncio presente una estructura distinta, entonces el destinatario se ve obligado a realizar un esfuerzo suplementario para lograr saber de qué tipo anuncio se trata.

En cuanto a la intertextualidad, son frecuentes los anuncios que recurren a otros tipos de mensajes con diversa finalidad. Hay anuncios que imitan cuadros famosos (la inserción de Farenheit recuerda un célebre cuadro de Caspar David Fiedrich), otros remedan corrientes pictóricas (La campaña de Alimentos de Andalucía emplea como imagen un bodegón de aire cubista pretendidamente picassiano), otros se inspiran en expresiones verbales lexicalizadas ("Mejora tu tren de vida", RENFE), otros se modelan a partir de esquemas textuales conocidos ("Se abre la puerta sin aviso previo. Él regresa antes que de costumbre. Ella lo advierte por el espejo. Está adorable. Como siempre. Su varonil elegancia. Ésa, su mirada cariñosa. ¡Cuánto esperó este momento! Luce el vestido nuevo. Con las más joyas hermosas. Y Gucci No 3. La fragancia que lo hipnotiza"), y otros, en fin, parodian anuncios de campañas pasadas (la reaparición, retocada y actualizada, de la vieja melodía de Cola-Cao) o de otras marcas ("A este anuncio le sobra el paisaje, el mar y la chica. Porque sólo vendemos un coche", Volkswagen). Como puede observarse, en la intertextualidad existe siempre un elemento A (el mensaje publicitario en cuestión) y otro B (el texto o imagen al que se remite). Para la correcta interpretación del mensaje es necesario que el receptor conozca $\mathrm{B}$, ya que si lo ignora o desconoce, el mensaje pierde parte de su fuerza y, por tanto, de su efectividad.

\subsection{Definición de forma publicitaria}

Según lo anteriormente dicho, un texto es, para la semiótica, un conjunto coherente de signos y, para los estudios textuales, una unidad de comunicación e interacción social, cuya composición varía enormemente, que se transmite a un receptor con la finalidad de transformar su actitud y que debe cumplir una serie de normas para ser considerado como tal. La aceptación de ambos puntos de vista permite que pueda decirse lo mismo de la forma publicitaria. He aquí la definición de forma publicitaria a partir de los postulados antes vistos.

1. Es un conjunto coherente de signos. La forma publicitaria es la conjunción de una serie de elementos de diversa naturaleza (visuales y sonoros, icónicos y simbólicos). Ahora bien, esta conjunción no es una mera suma de elementos. No están yuxtapuestos. Todos y cada uno de ellos guardan entre sí relaciones de diferente índole, de manera que la imagen no se explica sin el texto, o éste modifica su significado, o lo refuerza. O la inversa, es la imagen la que incide sobre el texto. O ambos se influyen mutuamente. El sentido final del mensaje publicitario, por tanto, no deriva de 
Juan Rey

un solo signo sino de la interacción de todos ellos, interacción que resulta más compleja si se tiene en cuenta que cada uno por separado genera a su vez significados tanto en el terreno de la denotación como de la connotación. Sin embargo, a pesar de esta plurisignificación, todos y cada uno de los significados parciales o secundarios contribuyen a la creación de un significado único, unívoco y unitario, que es el que percibe el destinatario. En caso de que no sucediera así, la comunicación publicitaria habría fallado.

2. Es una unidad de comunicación. La forma publicitaria es la unidad empleada en el intercambio comunicativo que llevan a cabo el anunciante y el cliente potencial. $\mathrm{O}$ más exactamente: el anunciante con el cliente potencial, ya que en la publicidad, como en toda comunicación masiva, el receptor no tiene posibilidad de convertirse a su vez en emisor y la única respuesta que le queda es la acción (comprar el producto o servicio) o la no acción (no comprar). Sin embargo, si se repasa la historia de la publicidad, se observa que el valor y el carácter de esta unidad de comunicación (el mensaje) ha variado a lo largo del tiempo (Casetti, 1994).

3. Su composición varía enormemente. La forma publicitaria presenta una enorme diversidad. Hay formas muy simples: un mechero con la marca de un producto. $Y$ otras más complejas: un spot o un banner. El hombre moderno vive rodeado de formas publicitarias. Son tantas que han terminado convirtiéndose en transparentes. No las ve. Camina por las calles sin percatarse de que ha pasado junto a un mupi donde se anuncia una ginebra, o que enfrente tiene una valla en la que se publicita una nueva marca de vaqueros, o que muy cerca circula un autobús que lleva en el costado un cartelón con la promoción de una cadena de supermercados, o que una linda patinadora le entrega un folleto de una agencia de viajes, o que un fornido mozalbete le ofrece una invitación para la inauguración de un bar de copas. Decenas de formas. Una visuales, otra auditivas, otras audiovisuales. Unas temporales, otras espaciales. Una bidimensionales, otras tridimensionales. Todas distintas. Unas próximas, otras lejanas. Una manipulables, otras inabarcables. Todas diversas. Unas convencionales, otras novedosas. Unas clásicas, otras modernas, otras vanguardistas. Unas originales, otras archiconocidas. Todas diferentes. Unas constituidas sólo por un texto; otras, por un texto y una imagen; otras, por imágenes, música y palabras. Decenas de formas que cada día, siguiendo las innovaciones técnicas, crecen, se multiplican, se transforman. Esta diversidad de formas tiene su origen en la variedad de canales por la que se transmiten los mensajes. No es lo mismo percibir un mensaje por el canal visual que por el auditivo o el audiovisual. Cada uno de ellos determina la presencia/ausencia de unos u otros integrantes que, a su vez, condicionan la organización global del mensaje.

4. Se transmite a un receptor con la finalidad de transformar su actitud. Si ninguna comunicación es gratuita, mucho menos lo es la publicitaria. Un anunciante no realiza una inversión publicitaria con fines filantrópicos sino económicos. De ahí que, cuando una empresa contrata los servicios de una agencia de publicidad, lo entienda como una inversión. El objetivo, por tanto, de la comunicación publicitaria es modificar la conducta del destinatario. En otras palabras: intentar que el público objetivo deje de ser mero receptor del mensaje para convertirse en consumidor del producto o servicio que publicita. En otros términos, lograr que el destinatario se transforme en cliente. 
5. Debe cumplir una serie de normas. Si cualquier texto, para ser considerado como tal, ha de cumplir las mencionadas normas de textualidad, no es necesario insistir ahora en la importancia que dichas normas tienen para el mensaje publicitario, porque, si es cierto que todo texto nace de una necesidad y tiene una intención, también es cierto que estos condicionantes se acentúa desmesuradamente en el caso del mensaje publicitario. No es, por tanto, necesario redundar en lo dicho anteriormente.

\section{EL DISCURSO PUBLICITARIO}

Si para dar una definición de forma publicitaria se ha partido de la noción de texto, para proporcionar la de discurso publicitario es necesario definir, en primer lugar, qué es el discurso y, después, qué es la publicidad. ¿Qué se entiende por discurso? En el seno de los estudios textuales existe una polémica acerca de las nociones de texto y discurso. Para unos son la misma cosa. Para otros, distintas, aunque estrechamente relacionadas. Sin embargo, desde el punto de vista de los estudios publicitarios, esta distinción resulta de suma utilidad, ya que en cierto modo viene a corroborar la definición de forma y discurso publicitarios dada anteriormente: la forma es la materialización del discurso publicitario y éste son los conceptos que se materializan en la forma.

\subsection{El discurso}

En su Ideología, Teun A. van Dijk parte de la dificultad que supone saber de qué se está hablando cuando se habla de discurso, ya que esta noción es ambigua, unas veces, y confusa, otras. En su afán de delimitar su objeto de estudio, establece siete definiciones de discurso: el discurso como un evento comunicativo (emisor-receptor), un producto verbal (una conversación o un texto), un objeto particular y único (el discurso del Presidente), un tipo abstracto (un contenido y una forma), un género específico (el discurso publicitario), una cuasi ideología (próxima a la ideología) y noción extendida de discurso (el cine, la música o la danza) (1999: 246-251).

De estas siete definiciones, unas resultan más interesantes que otras para el objetivo del presente trabajo, ya que no puede perderse de vista que se ha establecido que el discurso es el soporte conceptual en el que se apoya la forma. En este sentido, quizás las más útiles sean las definiciones quinta, cuarta y sexta. Es decir, aquellas que, respectivamente, definen el discurso como un género específico, un tipo abstracto y muy próximo a la ideología. En cuanto al discurso como género específico, cuando se habla de discurso publicitario se está aludiendo a un dominio social muy delimitado (la publicidad), pero se está haciendo de forma genérica, dado que el término discurso no se refiere a una forma publicitaria determinada ni a una manifestación publicitaria concreta, sino a todas las formas, todos los tipos, todas las expresiones y todas las manifestaciones que se llevan a cabo en el ámbito de la publicidad. En cuanto al discurso como tipo abstracto, hablar del discurso publicitario es referirse a toda una serie de mensaje que: a) todos son portadores de un contenido de carácter económico-publicitario, y b) todos presentan un conjunto de características formales y de tratamiento que los hacen identificables, reconocibles y agrupables. Estas dos concepciones del discurso se complementan con las definiciones segunda (el discurso como producto verbal) y séptima (la noción extendida de discurso). En cuanto al discurso como cuasi ideología, hablar del discurso publi- 
Juan Rey

citario es hacerlo del discurso de una época, de una cultura y de un ámbito geopolítico, ya que la publicidad es un fenómeno del mundo contemporáneo y es inherente a la sociedad de consumo, que, a su vez, está estrechamente vinculada a la ideología capitalista y a un espacio determinado (el triángulo de oro: Norteamérica, Europa y Extremo Oriente).

\subsection{La publicidad}

Si desde una perspectiva discursiva-ideológica, el discurso publicitario es aquél que transmite una ideología, ésta sin duda es la publicitaria. Es decir, el discurso publicitario, aquél que vehicula información, conocimientos, conceptos o ideas relativos al ámbito de la publicidad. Pero ¿qué es la publicidad? Estas son algunas de las definiciones más sobresalientes.

Según la Ley General de Publicidad, "Publicidad es toda forma de comunicación realizada por una persona física o jurídica, pública o privada, en el ejercicio de una actividad comercial, industrial, artesanal o profesional, con el fin de promover de forma directa o indirecta la contratación de bienes muebles o inmuebles, servicios, derechos y obligaciones" (Art. 2-1 de la Ley 34/1988 de 11 de noviembre). En esta definición, a pesar de las carencias que presenta, aparece ya una serie de elementos básicos que definen la publicidad y que, en mayor o menor medida, van a recoger las cientos de definiciones que existen de publicidad. A saber, que la publicidad es: a) una forma de comunicación, b) ligada al ámbito comercial e industrial, y c) cuyo fin es promover la compra bienes o servicios.

El ya clásico texto de José Ramón Sánchez Guzmán afirma que "el sistema publicitario es una red organizada de elementos, inscrita en el entorno general de la comunicación de masas, programados según un plan determinado para realizar objetivos cuyo marco de referencia es el universo económico de la empresa capitalista" (1993: 72). Además del análisis de la publicidad desde la teoría de los sistemas ("una red organizada de elementos"), esta definición incide en que la publicidad se halla vinculada a los medios de comunicación de masas y al ámbito económico de la empresa capitalista. Esta última característica, a pesar de ser obvia, no figura en numerosas definiciones y, sin embargo, es el rasgo que sirve para diferenciar el publicitario de otros discursos. Según la definición sexta, el discurso es frontero con la cuasi ideología. Es decir, el discurso es ya una ideología. Y evidentemente, en este caso esa ideología es la capitalista.

Enrique Ortega define la publicidad como un "proceso de comunicación de carácter impersonal y controlado que, a través de medios masivos, pretende dar a conocer un producto, servicio, idea, o institución con objeto de informar o de influir en su compra o aceptación" (1997: 22). Aun manteniéndose en el marco de la definición general de publicidad, ésta aporta algunas innovaciones. Primera: el hecho de ser una comunicación controlada por el emisor. Segunda: no sólo pretende promover un producto o servicio, también puede vender una idea o una institución. Y tercera: su finalidad es informar o influir. Una definición similar es la que proporciona el Diccionari de comunicació empresarial, publicitat, relacions pùbliques y màrqueting (1999) cuando define la publicidad como una "comunicación persuasiva y/o informativa sobre los productos, servicios, marcas, etc. de un anunciante, a través, fundamentalmente, de anuncios suscritos y pagados por el anunciante, y que tiene 
Forma, discurso e ideología en el mensaje publicitario

como objetivo incidir directa o indirectamente en los comportamientos de compra y consumo de los públicos a los que se dirige".

Y por último, Mario Herreros, en una definición que es quizás la más completa y la más compleja de cuantas pueden recopilarse, establece que:

Las características funcionales de la comunicación publicitaria pueden resumirse así:

Se ocupa de producir y difundir conocimientos o de estimular sensaciones sobre productos o servicios capaces de ser comercializados en los mercados de libre competencia.

Intenta establecer, a través de sus mensajes, la relación última de la cadena de comercialización entre compradores y vendedores del último escalón.

Su ámbito de actuación se circunscribe a los intereses privados propios del mundo del comercio. No obstante, en la actualidad [...], existen manifestaciones que, aunque persiguen objetivos distintos a los de comercialización, por su parecido en las formas, reciben sin embargo el calificativo de publicitarias en el lenguaje ordinario de gran parte de los profesionales.

Los argumentos y motivaciones empleados para enaltecer los productos objeto de la comunicación se fundamentan, por lo general, en los valores sociales vigentes, fuera de los estrictamente ligados a la materialidad de los productos o servicios.

Su dimensión como actividad económica subsidiaria está ligada a la comunicación pública de las empresas. Supone, a su vez, un sector económico independiente, en cuanto constituye una parte de la industria de la persuasión. Por último, la comunicación publicitaria en este aspecto se convierte en una de las principales fuentes de financiación de una actividad social tan importante e inexcusable como son los medios de comunicación de masas.

Al igual que MacQuail entiende en el plano específico de la información proporcionada por los medios de comunicación de masas, la publicidad suministra conocimientos sobre productos y servicios, sus formas de utilización y las relaciones establecidas entre los mismos y las distintas facetas de la actividad social e individual del consumidor. La publicidad cumple como transmisora de conocimientos ligados a la esfera de lo público, en relación con su juego en el sistema de producción y comercialización de los productos.

La publicidad es un género de comunicación que actualmente supone un claro y evidente testimonio explícito de la cultura material e inmaterial de la sociedad actual. Es decir, refleja los valores culturales y muestra los utensilios propios de una época (1999: 449).

Esta definición recoge algunos de los puntos tratados anteriormente y, al mismo tiempo, ofrece aspectos de la publicidad no señalados hasta. Al igual que otras muchas definiciones, también alude ésta a que la publicidad "suministra conocimientos sobre productos y servicios, [y] sus formas de utilización”. Sin embargo va más allá de la visión convencional cuando afirma que asimismo tienen como objetivo "difundir sensaciones" sobre dichos productos o servicios y "suministrar conocimientos sobre [...] las distintas facetas de la actividad social e individual del consumidor". Los mensajes, pues, ya no hablan sólo de las características del producto, de su utilidad o de los beneficios que proporciona, también recogen el universo en el que se desenvuelve el consumidor y en el que se consume la mercancía ("facetas de la actividad social e individual del consumidor"). Gracias a esta técnica de representación, 
la comunicación publicitaria actual no pretende tanto "suministrar conocimientos del producto" al viejo estilo como "estimular sensaciones", crear un universo en torno al producto y generar a su alrededor todo un sistema de valores cuya comunicación es más emocional que racional, más expresiva que argumentativa ("Los argumentos y motivaciones empleados para enaltecer los productos [...] se fundamentan en los valores sociales vigentes, fuera de los estrictamente ligados a la materialidad de los productos o servicios").

Por otra parte, esta definición incide especialmente en el carácter economicista de la publicidad, ya que, como subraya el autor, ésta es una actividad que "se circunscribe a los intereses privados propios del mundo del comercio" y que tiene como misión informar "sobre productos o servicios capaces de ser comercializados en los mercados de libre competencia", de manera que este tipo de comunicación constituye el último eslabón "de la cadena de comercialización entre compradores y vendedores". Pero no sólo se trata de una actividad que está vinculada al mundo económico, sino que, en el contexto de la sociedad moderna, la misma publicidad se ha erigido como "un sector económico independiente" en tanto en cuanto: a) "constituye una parte de la industria de la persuasión" y b) "se convierte en una de las principales fuentes de financiación de [...] los medios de comunicación de masas". En este sentido, la publicidad se incardina en el seno de la sociedad capitalista, forma parte sustancial de ella y, al mismo tiempo, es su más genuina expresión. El hecho de ser portavoz de la ideología capitalista es lo que determina su carácter mercenario y servil respecto de los valores de la sociedad en la que nace y de la que se nutre.

Muy vinculado a los dos aspectos anteriores se encuentra el punto cuarto, aquel que se afirma que "Ios argumentos y motivaciones empleados para enaltecer los productos [...] se fundamentan en los valores sociales vigentes, fuera de los estrictamente ligados a la materialidad de los productos o servicios". Por una parte, se insiste en el carácter economicista de la publicidad, ya que su función, en el seno de la sociedad de consumo, es "enaltecer los productos" a fin de modificar la conducta del receptor y hacerle pasar de destinatario a consumidor ("La publicidad cumple como transmisora de conocimientos ligados a la esfera de lo público, en relación con su juego en el sistema de producción y comercialización de los productos"). Y por otra, se incide en el empleo de argumentos ajenos a las características del producto para publicitarlo. Esta desviación del producto a su entorno, del producto a su consumidor o del producto a sus valores es la que ha hecho que la publicidad haya terminado convirtiéndose en "un claro y evidente testimonio explícito de la cultura material e inmaterial de la sociedad actual". Hoy la publicidad no es una mera comunicación comercial. Aunque vinculada indefectiblemente al mundo del comercio, no se circunscribe sólo a él, sino que lo ha desbordado y ha terminado convirtiéndose en un referente ideológico y cultural, referente que recoge los valores más destacados de la sociedad de consumo y, a modo de boomerang, los devuelve seleccionados, hermoseados, retocados... (Rey, 2008: 11-19). Y esto es ya ideología.

En última instancia, esta superación del ámbito comercial no es sólo ideológica. Según Herreros, también es formal: "En la actualidad [...] existen manifestaciones que, aunque persiguen objetivos distintos a los de la comercialización, por su parecido en las formas, reciben sin embargo el calificativo de publicitarias". En este sentido, hace casi cincuenta años que la política descubrió el caudal de ventajas que, para sus fines, le proporcionaba el empleo de formas de la comunicación publicita- 
Forma, discurso e ideología en el mensaje publicitario

ria. Más recientemente lo han hecho corporaciones, fundaciones e instituciones de diversa índole. Y mucho más recientemente las ONG. La agilidad, la rapidez, la versatilidad y la amenidad con la que la comunicación comercial publicita sus productos, de una parte, y la persuasión y eficacia logradas, de otra, hacen que otros organismos hayan terminado imitando su manera de hacer. Hoy, las formas publicitarias no se utilizan solamente para vender un detergente o un automóvil, también se emplean para promocionar la idea de solidaridad con el Tercer Mundo, la necesidad de usar el preservativo o la obligatoriedad de realizar la declaración de la renta. La publicidad ha desbordado, pues, el ámbito estrictamente comercial en el que nació y lo ha hecho en una doble dirección. Por un lado, ya no habla sólo de asuntos comerciales, también habla del universo del consumidor, de valores añadidos al producto o del imaginario colectivo relacionado con ese producto. Y por otro, organismos ajenos al mundo comercial han imitado su forma de comunicar. En cierto modo puede afirmarse que, en la actualidad, la publicidad lo inunda todo, inundación que ha suscitado las críticas y admoniciones de unos (apocalípticos) y la alabanza y felicitación de otros (integrados).

Debido al desarrollo económico de la sociedad de consumo, la publicidad se ha convertido a comienzos del siglo XXI en uno de los grandes discursos sociales, junto al discurso político, el científico, el religioso... En poco más de cien años ha pasado de ser un discurso de escasa incidencia social, un discurso además considerado innoble en tanto en cuanto no participaba de las categorías de las grandes artes y no tenía una finalidad estética sino funcional, a convertirse en un referente social. Hoy, la publicidad, al igual que los otros discursos sociales, e incluso con más poder de convocatoria y persuasión, modifica conductas, establece modelos de comportamiento y crea modas. No siempre fue así. Este cambio vertiginoso puede observarse en los aspectos formales de la propia publicidad. A fines del siglo XIX o comienzos del XX, la publicidad, en su afán de despojarse del aire mercantilista y funcional que la embargaba, procuraba imitar los grandes discursos consagrados socialmente, sobre todo los relacionados con la pintura. Era una manera de ocultar su finalidad comercial y ennoblecerse. En los años sesenta, el arte -con Roy Lichtenstein, Stuart Davis, Claes Oldenburg y Andy Warhol a la cabeza- imita las formas publicitarias. Esto demuestra la importancia e incidencia de la publicidad en la sociedad de consumo, en la que la publicidad se ha convertido en un discurso tan consagrado y tan aceptado que, incluso con más fuerza y persuasión que los discursos tradicionales, crea, modifica y justifica estilos de comportamiento y de vida.

\section{IDEOLOGÍA, DISCURSO Y FORMA PUBLICITARIOS}

Se ha dicho anteriormente que el discurso es cuasi ideología. Se trata, pues, de dos conceptos muy próximos que suelen confundirse y que, no obstante, nada tienen en común a no ser que aquél desempeña un papel primordial en la reproducción de ésta. Quizás esta confusión proceda de la importancia que el discurso tiene en la transmisión de la ideología, sin embargo no es el único medio para expresarla, ya que también puede manifestarse a través de fotografías, películas, exposiciones, manifestaciones, actitudes... La ventaja que, en este caso, presenta el discurso respecto de otros códigos es que "no sólo exhibe indirectamente las ideologías, tal como pueden hacerlo también otras prácticas sociales, sino que también formula explícitamente creencias ideológicas de manera directa" (Van Dijk, 1999: 245). El discurso, 
Juan Rey

al igual que otras prácticas sociales y otros códigos, aunque en mayor medida, se emplea para expresar o reproducir ideologías, entendiendo por éstas "representaciones sociales compartidas que tienen funciones específicas para los grupos" (1999: 243). En este sentido, la ideología publicitaria no es sino un subconjunto dentro del conjunto de la ideología economicista dominante en nuestra sociedad o ideología capitalista.

El estudio de la ideología es algo tan complejo que para su completa comprensión es necesario abordarla desde una triple perspectiva: social, cognitiva y discursiva (1999: 391-399). Desde el punto de vista sociológico, las ideologías son sociales en tanto en cuanto son practicadas en grupo. Una ideología es individual sólo en sus usos personales, sólo cuando los miembros de un grupo la aplican en un contexto determinado. Las ideologías no son sociales o culturales de manera general, sino que están definidas para grupos sociales específicos. Y no todas las colectividades de personas forman parte del grupo. Solamente la integran aquéllas que satisfacen los criterios de pertenencia. La reproducción de las ideologías necesita una organización e institucionalización en el seno de la sociedad. En este sentido, no todas las sociedades pueden ser calificadas de capitalistas. Sólo pueden serlo aquéllas que cumplas los criterios de pertenencia, es decir, las que reúnan las características propias de este tipo de sociedad.

Desde el punto de vista cognitivo, las ideologías son tanto mentales como sociales, ya que las propiedades mentales de las ideologías se adquieren, se comparten y se intercambian socialmente. Partiendo de la distinción tradicional entre creencias personales y creencias sociales (o representaciones sociales), la ideología se ubica en esta última en tanto en cuanto puede definirse como "creencias sociales compartidas de grupos sociales (específicos)" (1999: 392). Es decir, la ideología se define como un sistema general de creencias. Ahora bien, dado que hay multitud de creencias socialmente compartidas (valores, normas, actitudes...), es necesario redefinir la ideología como un sistema de creencias abstractas que subyacen a otras representaciones sociales y que, al mismo tiempo, están enraizadas en las creencias generales (conocimiento, opiniones, valores, criterios de verdad...) de toda una sociedad. Es necesario insistir en la noción de sistema, ya que la ideología no es un cúmulo de conceptos ni una lista de proposiciones, sino un sistema de valores coherente y jerarquizado cuya función es: a) representar la identidad social y los intereses del grupo, b) definir su cohesión y su solidaridad, c) organizar sus representaciones sociales, y d) controlar las creencias compartidas. En el caso concreto de la ideología publicitaria, ésta está constituida por todos los valores, opiniones, conocimientos, conductas y criterios relativos al ámbito económico en el que nace y se desarrolla la publicidad: el mundo capitalista, la sociedad de consumo.

Y desde el punto de vista discursivo, puede afirmarse que "las ideologías sociales de grupo controlan indirectamente las prácticas sociales, en general, y el discurso, en particular, a saber, por medio de las creencias sociales (conocimientos y actitudes) y las creencias personales (modelos)" (1999: 395). Es decir, el discurso desempeña un papel fundamental en la reproducción de la ideología, si bien las ideologías no pueden ser reducidas al discurso, ya que hay otras formas de expresar la ideología que superan la concepción tradicional de discurso tales como filmes, cuadros, conciertos, exposiciones, performances... En este sentido, cabe afirmar que la reproducción ideológica del discurso (ahora el término discurso debe ser comprendido en su sentido más amplio) es un complejo proceso social y cognitivo me- 
diante el cual los modelos mentales subyacentes son proyectados sobre las estructuras del discurso. Así surgen las autopresentaciones positivas del sujeto y las presentaciones negativas del otro. Esta estrategia de presentación interesada aumenta, disimula, potencia o mitiga las propiedades positivas o negativas del sujeto o de su adversario en función de sus intereses, y todo ello mediante el empleo intencionado y adecuada selección de palabras, imágenes, colores, melodías, argumentos... Basta observar detenidamente un anuncio para ver cómo el discurso publicitario presenta interesadamente el producto: potencia los factores positivos de la mercancía y elimina los negativos en el marco de un esquema formal aceptable y aceptado, y además los positivos son presentados de manera tal que al receptor le resultan sugerentes, atractivos, apetecibles, persuasivos en definitiva. Aun así, es necesario recordar que la influencia ideológica no sólo depende de lo que proponga el discurso, también depende del contexto social y de las representaciones mentales del receptor, ambos, a su vez, modelados a partir de la ideología imperante.

\section{A MODO DE CONCLUSIÓN}

Como colofón de todo lo expuesto anteriormente, puede afirmarse que (una parte de) la ideología de la sociedad de consumo se expresa y reproduce mediante el discurso publicitario y éste se encarna en las diferentes formas publicitarias. Se trata, por tanto, de tres conceptos cuyas relaciones son complejas y heterogéneas, pues, a veces, se solapan y, otras, se identifican. No obstante, como se ha visto, cada uno de ellos cumple funciones específicas. En principio, la forma publicitaria es la materialización del discurso publicitario y éste, por su parte, es una de las posibles manifestaciones de la ideología. Siguiendo un itinerario inverso, puede decirse que la ideología consumista se expresa mediante una serie de discursos, uno de los cuales es el publicitario, y que éste, a su vez, se encarna en las diferentes formas publicitarias.

\section{REFERENCIAS BIBLIOGRÁFICAS}

ADAM, J.M.; BONHOMME, M. La argumentación publicitaria. Retórica del elogio y de la persuasión. Madrid: Cátedra, 2000.

BEAUGRANDE, R.A.; DRESSLER, W.U. Introducción a la lingüística del texto. Barcelona: Ariel, 1997.

CASETTI, F. "Modelos comunicativos en publicidad". Questiones Publicitarias, $\mathrm{n}^{\circ} 2$ (1994), pp. 22-33.

ECO, U. La estructura ausente. Barcelona: Lumen, 1989.

HERREROS ARCONADA, M. "Teoría de la publicidad". En ARCEO VACAS, J.L. (ed.). Tratado de publicidad y relaciones públicas. Madrid: ICIE y Universidad Complutense, 1999, pp. 409-466.

LOZANO, J. et ali. Análisis del discurso. Madrid: Cátedra, 1993.

NÚÑEZ, R.; DEL TESO, E. Semántica y pragmática del texto común. Madrid: Cáte- 
Juan Rey

dra, 1996.

ORTEGA, E. La comunicación publicitaria. Madrid: Pirámide, 1997.

PANOFSKY, E. Estudios sobre iconología. Madrid: Alianza, 1994.

REY, J. (ed.). Publicidad y sociedad. Un viaje de ida y vuelta. Sevilla: Comunicación Social Ediciones y Publicaciones, 2008.

SÁNCHEZ GUZMÁN, J.R. Teoría de la publicidad. Madrid: Tecnos, 1993.

VV.AA. Diccionari de comunicació empresarial, publicitat, relacions públiques i marketing. Barcelona: TERMCAT / Enciclopèdia Catalana, 1999.

VAN DIJK, T.A. Ideología. Una aproximación interdisciplinar. Barcelona: Gedisa, 1999.

\section{Breve semblanza del autor}

Juan Rey es Doctor en Comunicación (sección Publicidad) y en Filología Hispánica. Actualmente es Profesor Titular de Universidad en el Departamento de Comunicación Audiovisual y Publicidad de la Facultad de Comunicación de la Universidad de Sevilla. Asimismo, es director del Grupo de Investigación en Métodos, Análisis y Estrategias de la Comunicación Empresarial e Institucional (MAECEI); del máster en Dirección de Comunicación; y de la revista Questiones Publicitarias. Sus líneas de investigación se centran en los aspectos redaccionales, simbólicos y formales de la publicidad, sobre los que ha publicado numerosos libros y artículos.

(Recibido el 12-12-07, aceptado el 13-02-08) 